\title{
Yenidoğan yoğun bakım ünitesindeki kültür ile kanıtlanmış sepsisli hastaların değerlendirilmesi
}

\author{
An evaluation of patients with culture-proven sepsis in a neonatal intensive care unit
}

\author{
Hülya Kara ${ }^{1}$, Sabahattin Ertuğrul ${ }^{2}$, Narin Gündoğuş ${ }^{3}$, Nezahat Akpolat ${ }^{3}$, Ömran Özmen ${ }^{1}$
}

\section{ÖZET}

Amaç: Yenidoğan yoğun bakım hizmetlerinin gelişmesine, tanı ve tedavideki ilerlemelere rağmen yenidoğan sepsisi önemli mortalite ve morbidite nedeni olmaya devam etmektedir. Bu çalışmada, takip ve tedavi ettiğimiz yenidoğanlarda görülen kültürle ispatlanmış sepsis olgularını değerlendirilmesi amaçlandı.

Yöntemler: Çalışma Eylül 2012 - Eylül 2014 tarihleri arasında kültürle kanıtlanmış sepsis tanısı alan yenidoğan hastalarının retrospektif olarak incelenmesi ile yapıldı. Kültürle kanıtlanmış sepsis tanısı alan olan 52 hasta çalışmaya dahil edildi.

Bulgular: Olgularımızın ortalama gebelik yaşı $32,75 \pm 1,45$ hafta ve ağırlık ortalaması $1895 \pm 516,49$ gramdı. Bunların 35 'i $(\% 67,3)$ prematüre ve 17 'si $(\% 32,7)$ term yenidoğandı. Çalışmadaki toplam 1641 hastadan 137'i (\%8) klinik sepsis tanısı aldı, bunlardan ise $52(\% 3,2)$ olguda kültür ile sepsisi tanısı kanıtlandı. Klinik sepsis tanısı alan olgularda kültür ile kanıtlanan sepsis sıklığı \%38 (52/137) idi. Olguların 3'ü $(\% 5,8)$ erken yenidoğan sepsis ve 49 'u $(\% 94,2)$ da geç yenidoğan sepsis tanısı aldı. Bu olguların \%50'de (26/52) retraksiyon en sık görülen, \%42,3 (22/52) bradikardi ikinci ve \%38,5 (20/52) beslenme intoleransı üçüncü en sık görülen bulguydu. Çalışmada \%46,1 olgu $(24 / 52)$ ile en fazla üreyen patojen Coagulase-negative staphylococci idi, ikinci en sık üreme \%21,2 (11/52) ile Klebsiella pneumoniae ve üçüncü en sık üreme $\% 9,6$ $(5 / 52)$ ile Escherichia coli üremesi olmuştu.

Sonuç: Yenidoğan yoğun bakım ünitelerinde elde edilen kan kültür sonuçları üniteler arasında farklılıklar gösterebilir ve ayrıca antimikrobiyal tedavi duyarlıı̆ı da değişebilir. Bu nedenle her ünite kültür sonuçlarına göre yenidoğan sepsis için tedavi stratejileri oluşturmaları gerekmektedir.

Anahtar kelimeler: Sepsis, yenidoğan, kan kültürü

\begin{abstract}
Objective: Despite in diagnosis, treatment and the development of the neonatal intensive care, neonatal sepsis continues to be an important cause of morbidity and mortality. In this study, we aimed to evaluate that having followed and treated in neonates with culture-proven sepsis.

Methods: Between September 2012 -2014, the retrospective analysis was performed in the diagnosis of neonatal patients with culture-proven sepsis. For this purpose, 52 patients who had been diagnosed with cultureproven sepsis were admitted in the study.
\end{abstract}

Results: The mean gestational age of patients was $32,75 \pm 1,45$ weeks, and the average weight was $1895 \pm 516,49$ grams. The patients were 35 (67.3\%) premature and 17 (32.7\%) term newborn. From sum of 1641 patients in our study had been diagnosed with sepsis 137 patients (8\%), and 52 of them (3.2\%) had a diagnosis of proven sepsis in patients with culture. Growth rate in culture for clinical sepsis patients were 38\% (52/137). They were diagnosed 3 patients $(5.8 \%)$ early neonatal sepsis and $49(94,2 \%)$ patients late neonatal sepsis. Retraction was the most common finding $50 \%$ (26/52), bradycardia second $42.3 \%(22 / 52)$ and feeding intolerance the third $38.5 \%(20 / 52)$ were other common findings. The first three agents in positive blood cultures were Coagulasenegative staphylococci 46.1\% (24/52), Klebsiella pneumoniae 21.2\% (11/52) and Escherichia coli 9.6\% (5/52).

Conclusion: Blood culture results obtained may vary between units and also vary in sensitivity to antimicrobial therapy. Therefore, each unit should establish treatment strategies for sepsis in units according to the culture results are obtained.

Key words: Sepsis, newborn, blood culture

\footnotetext{
${ }^{I}$ Dicle Üniversitesi Tıp Fakültesi Çocuk Sağlığı ve Hastalıkları AD, Diyarbakır, Türkiye

${ }^{2}$ Dicle Üniversitesi Tıp Fakültesi Çocuk Sağllğı ve Hastalıkları AD, Neonataloji Bilim Dalı, Diyarbakır, Türkiye

${ }^{3}$ Dicle Üniversitesi Tıp Fakültesi Tibbi Mikrobiyoloji AD. Diyarbakır, Türkiye

Yazışma Adresi /Correspondence: Sabahattin Ertuğrul,

Dicle Üniv. Tıp Fakültesi Çocuk Sağlığı ve Hastalıkları AD, Neonataloji BD. Diyarbakır, Türkiye Email: sertugrul68@yahoo.com Geliş Tarihi / Received: 01.07.2015, Kabul Tarihi / Accepted: 30.09.2015

Copyright (C) Dicle Tıp Dergisi 2015, Her hakkı saklıdır / All rights reserved
} 


\section{GíRiș}

Yenidoğan sepsisi yaşamın ilk 28 gününde ateş veya diğer sistemik enfeksiyon bulgularının olduğu ve kandan etken patojenin izole edildiği klinik sendromdur. Yenidoğan yoğun bakım ünitelerinin (YYBÜ) hizmetlerinin gelişmesine, tanı ve tedavideki ilerlemelere rağmen yenidoğan sepsisi, hem gelişmiş, hem de gelişmekte olan ülkelerde yenidoğanın önemli mortalite ve morbidite nedeni olmaya devam etmektedir [1]. Yenidoğan sepsisinin siklığı bin canlı doğumda 1-5'tir ve bu sıklık perinatal risk faktörlerine, prenatal bakıma ve ekonomik standartlara göre değişebilmektedir [2]. Yenidoğan sepsisi görüldüğü zamana göre erken ve geç başlangıçlı sepsis olarak tanımlanmakta, bu tanımlamalara göre de etiyolojik ajan, klinik görünüm ve tedavi değişiklikler gösterebilmektedir. Sepsisin hızlı ilerlemesi ve ölümün \%13-25 gibi yüksek sıklıklarda görülmesi nedeniyle tanının erken konması gerekmektedir [3]. Günümüzde sepsis tanıs1, iyi bir fizik muayene yanında, yardımcı laboratuar teşhis yöntemlerine dayanmaktadır. Yenidoğan sepsisinin tanısında kan kültüründe üreme olması kesin ve en değerli yöntem olarak kabul edilmektedir [4].

$\mathrm{Bu}$ çalışmada 2012 - 2014 y1llarında YYBÜ'mizde takip ve tedavi edilen kültürle kanıtlanmış sepsis tanısı alan yenidoğan olguları ve bu kültürlerde üreyen etken mikroorganizmalar değerlendirildi.

\section{YÖNTEMLER}

Çalışma Eylül 2012 - Eylül 2014 tarihleri arasında Dicle Üniversitesi Tip Fakültesi Neonatoloji Bilim Dalı YYBÜ'de kültürle kanıtlanmış sepsis tanısı alan yenidoğan hastalarının dosyalarının retrospektif olarak incelenmesi ile yapıldı. Bu amaçla belirtilen tarihler arasında yatan 1641 olgudan, kültürle kanıtlanmış sepsis tanısı almış olan 52 olgu çalışmaya dahil edildi. Çalışma Dicle Üniversitesi Tıp Fakültesi Klinik Araştırmalar Etik Kurulundan onay alınarak yapıldı.

\section{Hastaların araştırmaya dahil edilme kriterleri:}

1- Klinikte sepsis ön tanısı alıp kültür sonucunda etken patojen tespit edilip kültürle kanıtlanmış sepsis tanısinin olmas1

2- Yenidoğan yoğun bakım ünitesinde yatmış olmak
Hastaların araștırmaya dahil edilmeme kriterleri:

1- Klinik anlamlı bulunmayan üremeler

2- Meningiomyelosel, hidrosefali, ensefelosel ile birlikte sepsis tanılı hastalar

3- Herhangi bir cerrahi müdahale geçiren hastalar

Çalışmaya alınan her hasta için form hazırlanıp, hastaların demografik ve klinik özellikleri ile laboratuar bulguları kaydedildi. Hastaların doğum haftas1, doğum ağırlığı, postnatal yaşı, cinsiyeti, sepsis tanısı konduğundaki klinik bulguları (solunum, kardiyovasküler ve gastrointestinal sistem bulguları gibi), kateter takılıp takılmadığı, beyaz küre, trombosit sayıs1, C-reaktif protein (CRP) ve kan kültüründe üreyen etken patojenler kaydedildi. Sepsis tedavi sonuçları değerlendirildi.

Dört günden önce sepsis tanısı alan hastalar erken neonatal sepsis (ENS), dört günden sonra sepsis tanısı alanlar ise geç neonatal sepsis (GNS) olarak kabul edildi. Erken ve geç sepsis olarak 2 grup arasında karşılaştırmalar yapıldı. Etken patojene göre gruplar oluşturulup birbirleri ile karşılaştırıldı.

Çalışmamızdaki kültürler Dicle Üniversitesi Tıp Fakültesi Mikrobiyoloji Laboratuarında ve biyokimyasal tetkikler Dicle Üniversitesi Tip Fakültesi Biyokimya ve Klinik Biyokimya Laboratuarlarinda yapıldı.

\section{Laboratuar incelemeleri}

Kültür alınması için; cilt alanı iyot-alkol solüsyonu ile temizlendikten sonra periferik venden alınan 0.5$2 \mathrm{ml}$ kan, kültür şişesi vasatlarına steril şekilde aktarıldı. Kültür şişeleri BACTEC 9120 (Becton-Dickinson, ABD) cihazına yerleştirildi. Daha sonra cihazdan negatif ve pozitif alarm veren şişeler çıkarıld1. Negatif şişeler üreme yönünden negatif olarak kabul edildi. Pozitif şişelerin ise her biri kanlı, EMB (eozin metilen blue) ve SDA (sabouraud dekstroz agar) besiyerlerine ekildi. Ekilen besiyerleri etüvde 24 saat $37^{\circ} \mathrm{C}$ 'de tutulduktan sonra üremeler değerlendirildi. Besiyerlerinde üreme olanlarda mikroorganizmanın identifikasyon ve antimikrobiyal duyarlılığ1 için PhoenixTM 100 (Becton-Dickinson, ABD) otomatize sistemi kullanıldı.

Beyaz küre sayıs1, hemoglobin ve trombosit gibi hematolojik parametrelerin tespiti için yaklaşık 1 mililitre venöz kan EDTA içeren hemogram tüpü- 
ne kondu. Beyaz küre sayısı ile hemoglobin ve trombosit gibi hemotolojik parametreleri tespit ederken Cell-Dyn RubyTM (Beckman Coulter, ABD) otomatik hemogram cihazı kullanıldı. Çalışmamızda; beyaz küre say1s1; >20000/mm3 lökositoz, <5000/ mm3 lökopeni, trombosit sayıs1 <140000/mm3 trombositopeni olarak kabul edildi.

CRP tayini için $2-3$ cc kan kuru tüpe alındı. Kuru tüp içindeki kan 3500 devir/dk'da 5 dakika çevrilip ve serumu ayrıştırıldı. CRP için İmmageTM 800 (Beckman Coulter, ABD) cihazında İmmageTM (Beckman Coulter, ABD) ticari kiti kullanılarak immünoturbidimetrik yöntemle CRP düzeyleri kantitatif olarak ölçüldü ve $>0,60 \mathrm{mg} / \mathrm{L}$ üzerindeki düzeyler anlamlı kabul edildi.

\section{BULGULAR}

Çalışmada 1641 hastadan 137 (\%8) hasta klinik sepsis tanısı aldı bunlardan kültür ile kanıtlanmış sepsis tanısı alan $52(\% 3,2)$ hasta çalışmaya dahil edildi. Klinik sepsis tanısı alan hastalarda kültür ile kanıtlanmış sepsis sıklığ $\% 38$ (52/137) tespit edildi. Bu hastaların 3'ü $(\% 5,8)$ ENS ve 49'u $(\% 94,2)$ da GNS tanısı aldı. Hastaların ortalama gebelik yaşı $32,75 \pm 1,45$ hafta ve ağırlık ortalaması $1895 \pm 516,49$ gram olarak bulundu. Kültür ile kanıtlanmış sepsis tanıs1 alan 52 bebeğin 28 'i $(\% 53,8)$ erkek ve 24 'ü $(\% 46,2)$ kız hastalardan oluştu. Hastaların 35'i $(\% 67,3) 37$ gebelik haftasından veya daha küçük olan prematüre ve 17'si $(\% 32,7) 37$ gebelik haftasından daha büyüktü (Tablo 1).
Tablo 1. Sepsisli yenidoğanların demografik özellikleri ve eksitus oranları

\begin{tabular}{|c|c|c|c|c|c|}
\hline & & $\begin{array}{l}\text { Olgular } \\
\text { n (\%) }\end{array}$ & $\begin{array}{c}\text { Geç Sepsis } \\
\text { n (\%) }\end{array}$ & $\begin{array}{c}\text { Erken Sepsis } \\
\text { n (\%) }\end{array}$ & $\begin{array}{c}\text { Eksitus } \\
\text { n (\%) }\end{array}$ \\
\hline \multirow{2}{*}{ Cinsiyet } & Erkek & $28(53,8)$ & $26(92,9)$ & $2(7,1)$ & $9(32,1)$ \\
\hline & $\mathrm{K} \mathrm{IZ}$ & $24(46,2)$ & $23(95,8)$ & $1(4,2)$ & $10(41,7)$ \\
\hline \multirow{4}{*}{ Gebelik haftası } & $>37$ & $17(32,7)$ & $16(94,1)$ & $1(5,9)$ & $5(29,4)$ \\
\hline & $34-37$ & $8(22,9)$ & $6(75)$ & $2(25)$ & $3(37,5)$ \\
\hline & $29-33$ & $12(34,3)$ & $12(100)$ & - & $5(41,7)$ \\
\hline & $\leq 28$ & $15(42,9)$ & $15(100)$ & - & $6(40)$ \\
\hline \multirow{4}{*}{ Doğum ağırlığı } & $\geq 2.500 \mathrm{gr}$ & $15(28,8)$ & $14(93,3)$ & $1(6,7)$ & $6(40)$ \\
\hline & $2.499-1.500 \mathrm{gr}$ & $19(36,5)$ & $17(89,5)$ & $2(10,5)$ & $6(31,6)$ \\
\hline & $1.499-1.000 \mathrm{gr}$ & $9(17,3)$ & $9(100)$ & - & $2(22,2)$ \\
\hline & $\leq 999 \mathrm{gr}$ & $9(17,3)$ & $9(100)$ & - & $5(55,6)$ \\
\hline Toplam & & 52 & $49(94,2)$ & $3(5,8)$ & $19(36,5)$ \\
\hline
\end{tabular}

Kültürle kanıtlanmış yenidoğan sepsis tanısı alan 52 hastamızdan 24'ünde $(\% 46,1)$ Coagulase-negative staphylococci (KNS) en fazla üredi, 11 'inde $(\% 21,2)$ Klebsiella pneumoniae (K. pneumoniae), 5 'inde $(\% 9,6)$ Escherichia coli (E.coli), 2 sinde $(\% 3,8)$ Acinetobacter baumannii (A. Baumannii), 2 hastada $(\% 3,8)$ Staphylococcus aureus $(S$. aureus) ve birer hastada $(\% 1,9)$ Enterococcus faecium, Enterobacter aerogenes, Streptococcus sabrinus, Candida spp, Serratia marcescens (S. marcescens), Klebsiella oxytoca, Streptococcus viridans (S. viridans) ve Achromobacter species üremeleri oldu (Tablo 3).

Çalışmada 24/52 $(\% 46,1)$ hastada KNS üremesi olmuştur. Coagulase-negative staphylococci üremelerde; 16 hastada $(\% 30,8)$ Staphylococcus epidermidis (S. epidermidis), 5 hastada $(\% 9,6)$ Staphylococcus haemolyticus (S. haemolyticus), 2 hastada $(\% 3,8)$ Staphylococcus warneri $(S$. warne- 
ri) ve 1 hastada $(\% 1,9)$ Staphylococcus hominis (S. hominis) üremesi oldu.

Tablo 3. Kan kültüründe üreyen etiyolojik ajanların dağılımı ve tanı esnasında C-reaktif protein (CRP) pozitiflikleri

\begin{tabular}{lccc}
\hline Üreyen Etken & $\mathbf{n}(\%)$ & $\begin{array}{c}\text { CRP+ } \\
\mathbf{n}(\%)\end{array}$ & $\begin{array}{c}\text { CRP- } \\
\mathbf{n}(\%)\end{array}$ \\
\hline $\begin{array}{l}\text { Coagulase-negative } \\
\text { staphylococci }\end{array}$ & $24(46,1)$ & $8(15,3)$ & $16(32)$ \\
Klebsiella pneumoniae & $11(21,2)$ & $11(21,2)$ & \\
Escherichia coli & $5(9,6)$ & $4(8)$ & $1(1,9)$ \\
Acinetobacter baumannii & $2(3,8)$ & $2(3,8)$ & \\
Staphylococcus aureus & $2(3,8)$ & $1(1,9)$ & $1(1,9)$ \\
Enterococcus faecium & $1(1,9)$ & $1(1,9)$ & \\
Enterobacter aerogenes & $1(1,9)$ & $1(1,9)$ & \\
Streptococcus sabrinus & $1(1,9)$ & & $1(1,9)$ \\
Candida spp & $1(1,9)$ & $1(1,9)$ & \\
Serratia marcescens & $1(1,9)$ & $1(1,9)$ & \\
Klebsiella oxytoca & $1(1,9)$ & $1(1,9)$ & \\
Streptococcus viridans & $1(1,9)$ & & $1(1,9)$ \\
Achromobacter species & $1(1,9)$ & $1(1,9)$ & \\
\hline Toplam & 52 & $32(61,5)$ & $20(38,5)$ \\
\hline
\end{tabular}

Çalışmada olguların ortalama beyaz küre sayıS1 $15804 \pm 7968,13 / \mathrm{mm} 3$ ve ortalama total nötrofil say1s1 $6324,06 \pm 2346,23 / \mathrm{mm} 3$ tespit edildi. Olguların 13'ünde $(\% 25,0)$ lökositoz vardı (ortalama $30890 \pm 7250 / \mathrm{mm} 3)$ ve 6 'sında $(\% 11,5)$ da lökopeni (ortalaması $3710 \pm 1170 / \mathrm{mm} 3$ ) olduğu görüldü. Çalışmada ortalama trombosit sayısı $211.000 \pm 13876 /$ $\mathrm{mm}^{3}$ idi. Çalışmada olguların 23'ünde $(\% 44,2)$ trombositopeni tespit edildi, trombositopeni olan hastalarda ortalama trombosit düzeyi $68630 \pm 2984$ / $\mathrm{mm}^{3}$ tespit edildi.

Çalışmada ortalama serum CRP düzeyleri $5,7 \pm 0,83 \mathrm{mg} / \mathrm{L}$ ' idi. Hastalardan 32'sinin $(\% 61,5)$ tanı esnasında CRP düzeyi yüksekti ve CRP düzeyi yüksek olan hastalarda ortalama CRP düzeyi $32,55 \pm 13,13 \mathrm{mg} / \mathrm{L}$ idi. Tan1 esnasında CRP düzeylerine göre etiyolojik ajanların dağılımı Tablo 3'te gösterildi.

Hastalardan 28 erkek hastanın 9'u (\%17,3) ve 24 kız hastanın 10'u (\%19,2) eksitus oldu. Hastaların eksitus durumları Tablo 1'te gösterilmiştir. Eksitus olan olguların tanı esnasında tümünde beyaz küre yüksekliği $(\% 36,5), 17$ hastada $(\% 32,7)$ CRP yüksekliği ve 9 hastada $(\% 17,5)$ da trombositopeni bulunmuştur.
Çalışmamızda K. pneumoniae üreyen 11 hastanın 6'sının $(\% 54,5)$ eksitus olduğu, S. epidermidis üreyen 16 hastanın 7'sinin (\%43,8) eksitus olduğu, E.coli üreyen 4 hastanın 2'sinin (\%50), S. aureus üreyen 2 hastanın 1 'inin $(\% 50), S$. haemolyticus üreyen 5 hastanın 1'inin (\%20) eksitus olduğu, $A$. baumannii üreyen 2 hastanın 1 'inin $(\% 50)$ eksitus olduğu ve $S$. hominis üreyen 2 hastanın 1'inin (\%50) eksitus olduğu görüldü.

Kan kültürü alındığında hastaların 12'sine $(\% 23,1)$ kateter tak1liyd 1 , hastaların 40'ına $(\% 76,9)$ ise kateter takılıydı. A. baumannii üremesi olan 2 hastada da, $S$. epidermidis üreyen 16 hastanın 4'ünde (\%25), S. aureus üreyen 2 hastanın 1'inde $(\% 50)$ ve $S$. haemolyticus üreyen 5 hastanın 1'inde $(\% 20)$ kateter takıliydı.

\section{TARTIŞMA}

Yenidoğan sepsisi antimikrobiyal tedavideki yeni gelişmelere ve destekleyici tedavideki ilerlemelere rağmen, özellikle prematüre ve düşük doğum ağırlıklı (DDA) yenidoğanlarda mortalite ve morbidite nedenleri arasında önemli bir yer tutmaktadır $[5,6]$. Tanısındaki zorluklar, mevcut klinik bulgularının nonspesifik olmas1, tan1 ve tedavide meydana gelebilecek gecikmenin morbidite ve mortaliteyi artırması yenidoğan sepsisini daha da önemli bir hale getirmektedir [2]. Bu nedenle hastaların en kisa sürede doğru tanı ve tedaviyi alabilmeleri sağlanmalidir.

Yenidoğan sepsisi term erkek bebeklerde term k1z bebeklere oranla 2 kat daha fazla görülmektedir $[7,8]$. Sepsis için en önemli risk faktörü de prematüreliktir $[9,10]$. Bu çalışmada da sepsis tanısı alan olguların \%67,3'ü prematüre yenidoğanlardan oluşmakta ve hastalarımızın erkek/kız oran 1,16 olarak saptandı. Çalışmamızda gebelik haftası küçüldükçe kanıtlanmış sepsis sıklığ 1 artmakta ve çalışmamızda erkek cinsiyet lehine az da olsa bir farkın oluştuğu görülmektedir.

Yenidoğan bebeklerde sepsisin klinik belirtileri genel olarak solunum sikıntıs1, apne, beslenme intoleransı, karın şişliği, 1sı değişiklikleri, dolaşım bozukluğu, sarılık ve letarji veya irritabilite görülmektedir [11]. Bizim çalışmamızda hastalarımızın $\% 50$ 'sinde solunum sikintısinin bir bulgusu olan retraksiyon en s1k, bradikardi \%42,3 ikinci ve bes- 
lenme intolerans1 \%38,5 üçüncü en sık görülen bulguydu.

Yapılan çalışmalarda yendoğan sepsis başlangicında hastaların ancak 2/3'ünde anormal beyaz küre sayıları gözlenmektedir [12]. Yaptığımız bu çalışmada hastalarımızın \%25 lökositoz ve \%11,5 lökopeni tespit edilmiştir. Çalışmamızdaki hastalarımızın ortalama beyaz küre sayısı ve ortalama total nötrofil sayısı ise normal sınırlar içinde olduğu görüldü. Trombosit sayısının düşmesi yenidoğan sepsisinde geç ortaya çıkan nonspesifik bir bulgu olup yenidoğan sepsisinin erken tanısında çok güvenilir değildir [13]. Yapılan çalışmalarda yenidoğan sepsisinde trombositopeni insidans $1 \% 10-70$ arasinda bildirilmektedir [9]. Ancak diğer hematolojik parametrelerle birlikte değerlendirildiğinde sepsis tanısında yol gösterici olabilir. Çalışmamızda \%44,2 hastada trombositopeni tespit edildi. C-Reaktif protein, yenidoğan sepsisinin tanısında sık kullanılan bir testtir. Yapılan çalışmalarda CRP'nin düşük duyarlı11ğının olması nedeniyle, sepsisin erken döneminde CRP'yi tek başına yeterli tanısal bir test olmasını engellemektedir [14,15]. Yenidoğan enfeksiyonunu göstermede CRP'nin seri ölçümlerinin faydalı olduğu bildirilmiştir [2]. Bizim çalışmamızda tanı esnasında CRP pozitifliği \%55,8 tespit edildi. Kan kültürünün yenidoğan sepsis için duyarlılığı en iyi koşullarda \%50-80'dir. Kan kültürü yenidoğan sepsisinde tan1 koydurur, ancak negatif olması sepsisi ekarte ettirmez [16]. Bazı çalışmalarda sepsisli hastalarda kan kültürü pozitifliği için $\% 6$ ile $\% 82$ gibi çok farklı sonuçlar bildirilmiştir [9]. Ülkemizde yapılan çalışmalarda; Yıldız ve arkadaşları [14] \%65, İçağasığlu ve arkadaşları [17] \%46,7, Gürsu ve arkadaşları [18] \%48,3 kan kültüründe üreme olduğunu göstermişlerdir. Bizim çalışmamızda klinik sepsis tanısı almış hastalarda kültür ile kanıtlanmış sepsis sıklı̆̆ $\% 38$ bulundu.

Ülkemizde ENS ve GNS sılıl̆ğ ile ilgili yapılan çalışmalarda farklı sonuçlar bulunmaktadır [18-21]. Bizim çalışmamızda kültür ile kanıtlanmış sepsis kabul edilen hastaların $\% 5,8$ ENS ve $\% 94,2$ de GNS tespit edildi. Erken yenidoğan sepsis tanıs1 alan hasta sayımızın az olmasının nedeni, ünitemizin geniş bir bölgeye hizmet vermesi, hastanemizde doğmayan ve daha çok GNS tanısı alan hastaların kliniğimize yatırılmasından kaynaklanmaktadır.
Batı Avrupa ve ABD gibi gelişmiş ülkelerde ENS'nin en s1k etkeni olarak Group B streptococcus (GBS) izole edilirken bunu sirasiyla gram negatif basiller ve daha sonra da Staphylococcus'lar izlemektedir [22]. Gelişmekte olan ülkelerde ise ENS'de en sik izole edilen patojenin Klebsiella türleri olduğu, bunu S.aureus ve E.coli'nin izlediği, GBS'lerin sıklığının daha düşük olduğu bildirilmiştir [23]. Ülkemizde gebelerde GBS kolonizasyonu \%2-7 bulunmuş olup, ülkemizde yapılan çalışmalar gelişmiş ülkelerde rapor edilenin aksine ENS'de GBS'lerin en sık görülen patojenler arasında yer almadığını, Klebsiella türleri ve S. epidermidis' in sık görüldügünü göstermektedir [24,25]. Çalışmamızda erken ve geç neonatal sepsisli hiçbir hastada GBS üremesi olmadı. Çalışmamızda ENS tanısı alan 3 hastada üreme olmuş, bunlardan 2 hastada E.coli ve bir hastada S. warneri üremesi oldu.

Hastanede takip ve tedavi edilen DDA ve prematüre bebeklerde GNS riski daha yüksektir ve yapılan çalışmalarda KNS en sık etken patojen olarak görülmektedir [26-28]. S. aureus, E.coli, Klebsiella ve Enterococcus ise GNS'nin başlıca görülen diğer etkenleridir [29,30]. Ülkemizde yapılan çalışmalarda GNS'de en s1k KNS üremesi tespit edilirken, E.coli, K. pneumoniae, S. aureus ve Candida spp. diğer üreyen patojenler olmuştur $(13,14,19,25,31)$. Çalışmamızda ülkemizde yapılan çalışmalara benzer şekilde kan kültüründe $\% 46,1$ ile en fazla üreyen mikroorganizma KNS ve bunu \%21,2 ile $K$. pneumoniae izlemektedir. Diğer üreyen mikroorganizmalardan bazıları sirasıyla E.coli, A. baumannii ve $S$. aureus idi. Coagulase-negative staphylococci üremelerde; \%30,8 S. epidermidis, \%9,6 S. haemolyticus, $\% 3,8$ S. warneri ve $\% 1,9$ S. hominis üremesi oldu.

Yenidoğan sepsisinde mortalite en iyi merkezlerde bile \%10-40 gibi yüksek sayılabilecek bir düzeydedir [33,34]. Yenidoğan sepsisinde mortalite, ENS'de \%15-50 tespit edilirken, GNS' de bu \%10 20 olarak bulunmuştur $[8,9]$. Çalışmamızda ENS tanısı alan 3 hastanın hiçbirinde eksitus görülmezken, GNS tanısı alan \%36,5 eksitus oldu. Ancak çalışmamızda GNS'deki mortalitenin yüksek olmasının nedenini ENS'de kültürle kanıtlanma sıklığımızın düşük olmasından kaynaklandığını düşünmekteyiz. Prematüre yenidoğanlarda gebelik haftası azaldıkça mortalite riski artmaktadır [2]. Çalışmamızda eksi- 
tus olan 19 hastadan 14'ü $(\% 73,7)$ prematüreydi, bunlardan 6's1 $(\% 31,6) 28$ gebelik haftasinın altındaydı. Çalışmamızda ağırlığa göre değerlendirildiğinde DDA olanlarda da \%68,4 (13/19 hasta) ile mortalite daha yüksek tespit edildi. Bu sonuçlara bakıldığında çalışmamız gebelik haftası küçüldükçe ve doğum ağırlığ azaldıkça sepsise bağlı mortalite hızının yüksek olduğunu göstermiştir.

Sonuç olarak, bu çalışmayla yenidoğanın sepsisinin tanısının kültür ile kanıtlanmasının önemli olduğu vurgulanmıştır. Elde edilen kültürde üreme sonuçları üniteler arasında farklılıklar gösterebilir ve ayrıca antimikrobiyal tedavi duyarlılığı da değişebilir. Bu nedenle her ünite elde edilecek kültür sonuçlarına göre üniteleri için yenidoğan sepsisinde tedavi stratejileri oluşturmaları gerekmektedir.

\section{KAYNAKLAR}

1. Sundaram V, Kumar P, Dutta S, et al. Blood culture confirmed bacterial sepsis in neonates in a North Indian tertiary care center: changes over the last decade. Jpn J Infect Dis 2009;62:46-50.

2. Leonard EG, Dobbs K. Postnatal bacterial infections. In: Martin RJ, Fanaroff AA, Walsh MC, eds. Fanaroff and Martin's Neonatal-Perinatal Medicine, 10th edn. St. Louis: Elsevier Mosby Inc. 2015:734-750.

3. Gomella TL, Cunningham MD, Eyal FG. Neonatology, $6^{\text {th }}$ edn. New York: Lange Medical Books/ Mc Graw-Hill, 2009:665-672.

4. Annagür A, Örs R. Yenidoğan sepsisi. Selçuk Pediatri 2013;1:1-11.

5. Stoll B. The global impact of neonatal infection. Clin Perinat 1997;24:1-21.

6. Thaver D, Zaidi AKM. Burden of neonatal infections in developing countries: A review of evidence from communitybased studies. PIDJ 2009;28:S3-9.

7. Verani JR, Schrag SJ. Group B streptococcal disease in infants: progress in prevention and continued challenges. Clin Perinatol, 2010;37:375-392.

8. Ovalı F. Bakteriyel infeksiyonlar. In: Dağoğlu T, Ovalı F, eds. Neonatoloji. 2. baskı. İstanbul: Nobel Tip Kitabevleri Ltd., 2007:65-93.

9. Jiang JH, Chiu NC, Huang FY, et al. Neonatal sepsis in the neonatal intensive care unit: characteristics of early versus late onset. J Microbiol Immunol Infect 2004;37:301-306.

10. Stoll BJ, Hansen N, Fanaroff AA, et al. Late-onset sepsis in very low birth weight neonates: the experience of the NICHD Neonatal Research Network. Pediatrics 2002;110:285-291.

11. Ferrieri P, Wallen LD. Neonatal bacterial sepsis. In: Gleason CA, Devaskar SU, eds. Avery's Diseases of The Newborn,9th edn. Philadelphia: Saunders, an imprint of Elsevier Inc. 2012:538-550.

12. Newman TB, Puopolo KM, Wi S, et al. Interpreting complete blood counts soon after birth in newborns at risk for sepsis. Pediatrics 2010;126:903-909.
13. Meral C, Karademir F, Süleymanoğlu S, ve ark. Neonatal sepsis olgularının ve etkenlerinin retrospektif değerlendirilmesi. TAF Prev Med Bull 2009;8:329-332.

14. Yıldız C, Yıldız H, Kavuncuoğlu S, Şiraneci R. Yenidoğan sepsisinin erken tanısında prokalsitonin. Çocuk Sağlığı ve Hastalıkları Dergisi 2003;46:90-97.

15. Doellner H, Arntzen KJ, Haered P, et al. IL-6 concentrations in neonates evoluated for sepsis. J. Pediatr 1998;132:295299.

16. Cengiz AB. Yenidoğan sepsisinde değelendirme ve yönetim. Güncel Pediatri 2007;5:126-131.

17. Içağasıoğlu D, Caksen H, Sütcü I, Cevit O. Serum C-reaktive protein and interleukin-6 levels in neonatal sepsis. Acta Medica, 2002;45:111-113.

18. Gürsu HA, Vitrinel A, Cömert S, ark. Neonatal sepsisli olgularımızın prospektif değerlendirilmesi. Bakırköy Tıp Dergisi, 2007;3:89-93.

19. Bulut MO, Bulut İK, Büyükkayhan D, ark. Neonatal sepsisli olguların retrospektif olarak değerlendirilmesi. C. Ü. Tip Fakültesi Dergisi 2005;27:63-68.

20. Aygün C, Oran O, Portakal O. Yenidoğanlarda prokalsitonin düzeyleri ve sepsis tanısındaki yeri. Çocuk Sağlığı ve Hastalıkları Dergisi 2003;46:83-89.

21. Aksoy H, Orbay E, Akın Y, Vitrinel A. Neonatal sepsisli olguların retrospektif incelenmesi. Türk Aile Hek Derg 2002;6:18-23.

22. Edwards MS, Baker CJ. Sepsis in the newborn. In: Gershon AA, Hotez PJ, Katz SL, eds. Krugman's Infectious Disease of Children, 11.th edn. Philadelphia: Mosby, 2004;545-561.

23. Zaidi AK, Thaver D, Ali SA, Khan TA. Pathogens associated with sepsis in newborns and young infants in developing countries. Pediatr Infect Dis J 2009;28:10-18.

24. Resch B, Gusenleitner W, Müller WD. Procalcitonin and interleukin- 6 in the diagnosis of early-onset sepsis of the neonate. Acta Paediatr 2003;92:243-245.

25. Perk Y. Yenidoğan sepsisinde antibiyotik direncinin alt (2002-2007) yıllık Cerrahpaşa Tıp Fakültesi deneyimi. Cerrahpaşa Üniversitesi Tıp Fakültesi Çocuk Sağlığı ve Hastalıkları Anabilim Dalı Uzmanlık Tezi: İstanbul, 2010.

26. Garland SM, Bowman ED. Reappraisal of C-reactive protein as a screening tool for neonatal sepsis. Pathology 2003;35:240-243.

27. Makhoul IR, Sujov P, Smolkin T, et al. Epidemiological, clinical, and microbiological characteristics of late-onset sepsis among very low birth weight infants in Israel: a national survey. Pediatrics 2002;109:34-39.

28. Cengiz AB. Yenidoğan sepsisi. Çocuk Enf Derg 2009;3:174181

29. Haque KN. Definitions of bloodstream infection in the newborn. Pediatr Crit Care Med 2005;6:45-49.

30. Cohen-Wolkowiez M, Moran C, Benjamin DK, et al. Early and late onset sepsis in late preterm infants. Pediatr Infect Dis J 2009;28:1052-1056.

31. Kaynak Türkmen M, Telli M, Erişen S, ve ark. Neonatal sepsisli olguların değerlendirilmesi ve antibiyotik duyarlılıklarının belirlenmesi. ADÜ Tıp Fakültesi Dergisi 2010;11:15-20.

32. Klein JO. Bacteriology of neonatal sepsis. J Pediatr Infect Dis 1990;9:778.

33. Chacko B, Sohi I. Early onset neonatal sepsis. Indian J Pediatr 2005;72:23-62. 